\title{
Thermal properties of some selected nigerian soups
}

\author{
Raji Akeem Olayemi ${ }^{1}$, Akinoso Rahman ${ }^{2}$ \\ ${ }^{1}$ Department of Food Agric and Biological Engineering, College of Engineering and Technology, Kwara State University, Malete, \\ Ilorin, Nigeria; akeem.raji@kwasu.edu.ng \\ ${ }^{2}$ Department of Food Technology, University of Ibadan, Oyo State, Nigeria; akinoso2002@yahoo.com
}

Received 2013

\section{ABSTRACT}

A preliminary investigation was carried out on the thermal properties of "Ewedu" (Corchorusolitorus), "lla" (Hibiscus esculentus), "Ogbono" (Irvingia gabonensis) and "Kuka" (Adansonia digitata) soups, because information on the thermal properties of these soups has not been established. The specific heat capacity, thermal conductivity and thermal diffusivity parameters were determined as a function of their proximate compositions by applying additivity principles. The proximate composition obtained for the soups were: ewedu (moisture content; $88.60 \pm 0.14 \%$, protein; $6.00 \pm 0.01 \%$, fat; $1.05 \pm 0.05 \%$, ash; $1.81 \pm 0.01 \%$, crude fiber; $1.47 \pm 0.02 \%$, carbohydrate; $1.05 \pm$ $0.04 \%$ and energy $34.27 \pm 1.89 \mathrm{k} / \mathrm{cal} / 10 \mathrm{~g}$ ), lla (moisture content; $77.25 \pm 0.35 \%$, protein; 15.94 $\pm 0.08 \%$, fat; $2.13 \pm 0.04 \%$, ash; $1.90 \pm 0.14 \%$, crude fiber; $1.15 \pm 0.07 \%$, carbohydrate; $1.48 \pm$ $0.11 \%$ and energy $87.61 \pm 3.31 \mathrm{k} / \mathrm{cal} / 10 \mathrm{~g}$ ), Ogbono (moisture content; $68.87 \pm 0.14 \%$, protein; $18.70 \pm 0.42 \%$, fat; $6.12 \pm 0.11 \%$, ash; $4.55 \pm 021 \%$, crude fiber; $1.04 \pm 0.60 \%$, carbohydrate; $1.90 \pm$ $0.01 \%$ and energy; $133.08 \pm 0.60 \mathrm{k} / \mathrm{cal} / 10 \mathrm{~g}$ ) and Kuka (moisture content; $78.54 \pm 0.06 \%$, protein; $8.80 \pm 0.41 \%$, fat; $2.29 \pm 0.01 \%$, ash; $2.09 \pm 0.01 \%$, crude fiber; $0.88 \pm 0.02 \%$, carbohydrate; $7.42 \pm$ $0.08 \%$ and energy $85.64 \pm 0.17 \mathrm{k} / \mathrm{cal} / 10 \mathrm{~g}$ ). The specific heat capacity, thermal conductivity and thermal diffusivity for the soups were; ewedu $\left(3.851 \mathrm{~kJ} / \mathrm{kg} / \mathrm{K}, 0.530 \mathrm{~W} / \mathrm{m} / \mathrm{K}\right.$ and $1.358 \times 10^{-7}$ $\left.\mathrm{m}^{2} / \mathrm{s}\right)$, Ila $(3.554 \pm 0.01 \mathrm{~kJ} / \mathrm{kg} / \mathrm{K}, 0.483 \mathrm{~W} / \mathrm{m} / \mathrm{K}$ and $\left.1.281 \times 10^{-7} \mathrm{~m}^{2} / \mathrm{s}\right)$, ogbono $(3.332 \mathrm{~kJ} / \mathrm{kg} / \mathrm{K}, 0.447$ $\mathrm{W} / \mathrm{m} / \mathrm{K}$ and $\left.1.220 \times 10^{-7} \mathrm{~m}^{2} / \mathrm{s}\right)$ and kuka (3.586 $\mathrm{kJ} / \mathrm{kg} / \mathrm{K}, 0.494 \mathrm{~W} / \mathrm{m} / \mathrm{K}$ and $\left.1.296 \times 10^{-7} \mathrm{~m}^{2} / \mathrm{s}\right) \mathrm{re}-$ spectively. The values obtained for the thermal properties showed that the soups can mildly retain or dissipate heat during canning and freezing.

Keywords: Soups; Proximate Composition;
Thermal Properties; Processing

\section{INTRODUCTION}

Vegetables are important constituents of any type of diet in many Nigerian homes. Despite that, they add varieties to the menu. As valuable sources of nutrients especially in rural areas where they contribute substantially to protein, mineral, vitamins, fiber and other nutrients which are usually in short supply in most daily diets [1]. Besides, they add flavour, variety, taste, colour and aesthetic appeal to what would otherwise be a monotonous diet $[2,3]$. They are mostly in abundance shortly after the rainy season but become scarce during the dry season when cultivated types are used. Some eventually find their way to urban markets [1].Vegetables have gained a widespread acceptance as a dietary constituent in Nigeria, generally forming a substantial portion of the diet in the preparation of soups and stews[3].

Nigeria is a multi-cultural society with different traditional soups which are indigenous to different ethnic groups and tribes. The soups are consumed along with traditional dietary staples, obtained from cassava, yam, cocoyam, sweet potatoes, plantain and maize [4]. Though, there is no universally accepted short list of such plants mentioned above, different tribes in Nigeria have evolved their preferences and feeding habits.

During processing and storage, many foods are either heated or cooled. Cooling, cooking, pasteurization, dehydration, commercial sterilization and freezing involve heat transfer [5] and the design of such processes requires a detailed knowledge of the thermal properties of the materials involved.

Although the recipe and nutritional contents of stews and soups commonly consumed in Nigeria had been establihed in order to serve as a reference for interested individuals, corporate organizations, researchers, medical practitioners, nutritionists and dieticians, public health workers and food technology programmes [6], information on the thermal properties of these soups has not been established. The parameters stated above will serve as a 
basis for future research in canning of Nigerian soups and also establish the possibilities of extending the shelf life of the local soups under frozen storage. Soups to be considered are chosen because they are popularly consumed along with staple foods from the three major tribes in Nigeria and these are prepared from "Ewedu" (Corchorusolitorus), "Ila” (Hibiscusesculentus), “Ogbono" (Irvingiagabonensis) and " Kuka” (Adansoniadig itata).

\section{MATERIALS AND METHODS}

\subsection{Materials}

The ingredients used for the preparation of the above soups were purchased from Local markets at Ipata and Ago in Ilorin, Kwara State Nigeria.

\subsubsection{Preparation of Soups}

Selected Nigerian soups mentioned above were prepared using facilities of the department of Food Agric and Biological Engineering, Kwara State University Nigeria. The preparation methods used for the selected soups were those earlier established by recipe book of the Federal Institute of Industrial Research, Oshodi [6]. Each dish was prepared in triplicates and analyses were carried out on wet basis.

\subsubsection{Sample Collection and Preparation}

Each soup was cooled to room temperature and equal portions of the dishes were homogenized with a warring blender.

\subsection{Proximate Composition Analysis}

Each sample was analysed for moisture, ash, crude fat, and crude fiber using the methods of the Association of Official Analytical Chemists[7]. Nitrogen was determined by Kjeldahl method and percentage nitrogen was converted to crude protein by multiplying the value with 6.25[8]. Carbohydrate was determined by the difference

of the sum of all the proximate compositions from $100 \%$. The energy value was calculated using the Atwater factors of 4,9 , and 4 for protein, fat, and carbohydrate respectively [9].

\subsection{Determination of Thermal Properties}

The specific heat capacity, thermal conductivity and thermal diffusivity of the soups were determined as a function of their proximate compositions by applying additivity principles.

\subsection{Specific Heat Capacity (Cp) and Thermal Conductivity (K)}

The above parameters were determined based on weight fraction of water, fat, ash, protein and carbohydrate component of food using the equations stated below[10].

$$
\begin{gathered}
C_{p}=1.424 X_{c}+1.549 X_{p}+1.675 X_{f}+0.837 X_{a}+4.187 X_{w} \\
k=0.58 X_{w}+0.155 X_{p}+0.25 X_{c}+0.16 X_{f}+0.135 X_{a}
\end{gathered}
$$

\subsection{Thermal Diffusivity}

This was determined based on weight fraction of water, fat, protein and carbohydrate component of food using the equation stated below [11].

$$
\begin{aligned}
D= & 0.146 \times 10^{-6} X_{w}+0.10 \times 10^{-6} X_{f} \\
& +0.075 \times 10^{-6} X_{p}+0.082 \times 10^{-6} X_{c}
\end{aligned}
$$

$X$ was the fraction of food component, and the subscripts; $w, f, p, c$ and a represented water, fat, protein, carbohydrate and ash respectively.

\section{Statistical Analysis}

Data were reported as mean \pm standard deviation. Statistical analyses were carried out using SPSS for Win-

\begin{tabular}{|c|c|c|c|c|c|c|c|}
\hline Soups & MC\% & CHON\% & Fat $\%$ & Ash\% & CF\% & СНО\% & $E(\mathrm{k} / \mathrm{cal} / 10 \mathrm{~g})$ \\
\hline Ogbono & $68.70 \pm 0.14$ & $18.70 \pm 0.42$ & $6.12 \pm 0.11$ & $4.55 \pm 0.21$ & $1.04 \pm 0.60$ & $1.90 \pm 0.01$ & $133.08 \pm 0.60$ \\
\hline Ewedu & $88.60 \pm 0.14$ & $6.00 \pm 0.01$ & $1.05 \pm 0.05$ & $1.81 \pm 0.01$ & $1.47 \pm 0.02$ & $1.05 \pm 0.04$ & $34.27 \pm 1.89$ \\
\hline Ila & $77.25 \pm 0.35$ & $15.94 \pm 0.08$ & $2.125 \pm 0.04$ & $1.90 \pm 0.14$ & $1.15 \pm 0.07$ & $1.475 \pm 0.11$ & $87.61 \pm 3.31$ \\
\hline Kuka & $78.54 \pm 0.06$ & $8.80 \pm 0.14$ & $2.29 \pm 0.01$ & $2.09 \pm 0.01$ & $0.875 \pm 0.02$ & $7.415 \pm 0.08$ & $85.64 \pm 0.17$ \\
\hline
\end{tabular}
dows, version14.0 (SPSS Inc. Chicago, IL.USA).

\section{RESULTS}

Table 1. Proximate composition of some selected nigerian soups.

MC = Moisture Content(\% wb); CF = Crude Fibre(\% wb); CHON = Protein Content(\% wb); E = Energy,k/cal/10 g. 
Table 2. Thermal properties of some selected nigerian soups.

\begin{tabular}{cccc}
\hline Soups & $\boldsymbol{C}_{\boldsymbol{P}}(\mathrm{kJ} / \mathrm{kg} / \mathrm{K})$ & $\boldsymbol{K}(\mathrm{W} / \mathrm{m} / \mathrm{K})$ & $\boldsymbol{D}\left(\mathbf{m}^{2} / \mathbf{s}\right)$ \\
\hline Ogbono & $3.3315 \pm 0.00$ & $0.4470 \pm 0.00$ & $1.22 E-07$ \\
\hline Ewedu & $3.8505 \pm 0.00$ & $0.5295 \pm 0.00$ & $1.36 E-07$ \\
\hline Ila & $3.5535 \pm 0.01$ & $0.4825 \pm 0.00$ & $1.28 E-07$ \\
\hline Kuka & $3.5860 \pm 0.00$ & $0.4935 \pm 0.00$ & $1.30 E-07$ \\
\hline
\end{tabular}

$\mathrm{C}_{\mathrm{p}}=$ Specific Heat Capacity, $\mathrm{KJ} / \mathrm{Kg} / \mathrm{K} ; \mathrm{K}=$ Thermal Conductivity ,W/m/K; $\mathrm{D}=$ Thermal Diffusivity, $\mathrm{m} / \mathrm{s}^{2}$

\section{DISCUSSION}

The results of the proximate compositions and thermal properties of some selected nigerian soups were presented in Tables 1 and 2. The moisture content of the soups determine their suitability to microbial attack and hence spoilage [12]. The moisture content of "Ogbono" $(68.70 \pm 0.14 \%)$ is lower than those of "Ila", "Ewedu"and "Kuka. This indicated that Ogbono with lower moisture content, might have storage advantage over others. Ash content is an index of mineral contents in biota[13]. The observed ash content from the present study ranged between $1.81 \pm 0.01$ to $4.55 \pm 0.21 \%$, with Ogbono having the highest ash content. This could mean that the minerals in Ogbono are higher than that of others. Proteins are important in the body due to their numerous roles[14,15]. The protein content of the soups ranged from $6.00 \pm 0.01$ to $18.70 \pm 0.42 \%$, and Ogbono had the highest. Ewedu and Kuka with lower protein content $(6.00 \pm 0.01 \%$ and $8.80 \pm 0.14 \%)$ might not be able to contribute significantly to the daily protein requirements of 22 - $56 \mathrm{~g}$ [16]. Fats are saturated lipids at room temperature[17,15] which are known to play protective roles in the body system[12]. Some important fatty acids such as omega-3-fatty acid, etc, are derived from fats. These fatty acids are noted for their roles in the body system [18].The crude fat content of the soups were in the range of $1.05 \pm 0.05$ to $6.12 \pm 0.11 \%$. Variation in the fat contents might be as a result of different quantities of external red oil added to the soups as stated in the recipe book. Adequate intake of dietary fiber can lower the level of serum cholesterol and reduce the risk of developing hypertension, constipation, diabetes, colon, cancer and coronary heart disease [19]. The fiber content of the soups ranged between $0.875 \pm 0.02$ to $1.47 \pm 0.02 \%$, with having the highest fiber content. The recommended dietary allowance (RDA) values of carbohydrate for adults, pregnant and lactating mothers are 130 g, 175 g, and 210 g respectively [15]. The carbohydrate content and the estimated calorific value of the soups were very low, but this is not a concern since they are been consumed along with starch based dietary staples[4].

The thermal properties express the reaction of a substance when a change in temperature occurs. Specific heat capacity determines the amount of heat a substance can absorb [10]. The specific heat capacity obtained ranged from $3.3315 \pm 0.00$ to $3.8505 \pm 0.00 \mathrm{~kJ} / \mathrm{kg} / \mathrm{K}$. These values are slightly below the specific heat capacity of water. It has been proved that there is direct correlation between the specific heat capacity and moisture content of food product [20]. This implies that as the moisture content increases, the specific heat capacity increases. This was noticed in the soup samples, with Ewedu having the highest moisture content and specific heat capacity. The thermal conductivity of a material is a measure of its ability to transmit heat[21,10].The thermal conductivity estimated ranged between $0.4470 \pm 0.00$ and $0.5295 \pm$ $0.00 \mathrm{~W} / \mathrm{m} / \mathrm{K}$. Highest value was reported for Ewedu. This connotes that ewedu will have a greater advantage of absorbing and dissipating heat during processing and storage than others. It was observed that thermal conductivity of food depended on the structure and chemical composition of the sample and it increased with increasing water content for all food products at temperature above freezing [19]. Similar results were obtained in this study for the thermal conductivity of soups. The thermal diffusivity quantifies a material`s ability to conduct heat relative to its ability to store heat [11].The results obtained indicated that thermal diffusivity increased with increase in moisture content, as it was observed in thermal conductivity and specific heat capacity of the soup samples.

\section{CONCLUSIONS}

The present study shows that the chemical compositions and water fractions greatly influence the thermal properties of soups.

The values of the thermal properties obtained shows that the soups can considerably retain or dissipate heat during canning and freezing.

\section{REFERENCES}

[1] Mepba, H.D., Eboh, L. and Banigo, D.E.B. (2007) Effects of processing treatments on the nutritive composition and consumer acceptance of some Nigerian edible leafy vegetables. African Journal of Agricultural Nutrition and Development, 7, 1-18.

[2] Shiundu, K.M. (2002) Role of african leafy vegetables (ALVs) in alleviating fFood and nutrition insecurity in africa. AJFNS, 2, 96-97.

[3] Hart, A.D., Azubuike, C.U., Barimalaa, I.S. and Achinewhu, S.C. (2005) Vegetable consumption pattern of 
households in selected areas of the old Rivers State in Nigeria. African Journal of Food, Agriculture, Nutrition and Development, 5, No. 1.

[4] Kayode, F.O., Ozumba, A.U., Ojeniyi, S. Adetunji, D.O. and Erukainure, O.L. (2010) Micronutrient content of selected indigenous soups in nigeria. Pakistan Journal of Nutrition, 9, 962 - 965. do i : 10.3923/pjn.2010.962.965

[5] Oyelade, O.J., Odugbenro, P.O., Abioye, A.O. and Raji, N.L. (2005) Some physical properties of African star apple (Chrysophyllum alibidum) seeds. Journal of Food Engineering, 67, 435-440. doi:10.1016/j.jfoodeng.2004.05.046

[6] FIIRO, (2006) Soup Recipe Book. Federal Institute of Industrial Research, Oshodi, Nigeria.

[7] Association of Official Analytical Chemists (1990): Official Methods of Analysis, Association of official chemists, $15^{\text {th }}$ Edn.,Washington DC., Association of Official Analytical Chemists, 10-30.

[8] Pearson, D. (1976) Chemical Analysis of Foods. 7th Edn., Church Hill Livingstone, London, UK., 72-73, 138-143, 488-496.

[9] Onwuka, G.I. (2005) Food analysis and instrumentation (Theory and practice). 1st edn, Napthali prints, Surulere, Lagos - Nigeria. 140-160.

[10] Singh, R.P. and Heldman, D.R. (2000) Introduction to Food Engineering, Third Edition.Academic Press.

[11] Stroshine, R., Hamann, D.D.(1994) Physical properties of agricultural materials and food products. Course manual, Purdue University, USA.

[12] Olusanya, J.O. (2008) Essential of food and Nutrition.1st edition Apex book limited, 36-76.
[13] Akubugwo, I.E., Obasi, N.A., Chinyere, G.C. and Ugbogu A.E. (2007) Nutritional and chemical value of amaranthus hybridusL. leaves from Afikpo, Nigeria. African Journal of Biotechnology, 6, 2833-2839.

[14] Uwakwe, A.A. and Ayalogu, E.O. (1998) Proteins, In: Biochemistry (A tropical approach), FIUS Publishers, Port Harcourt, 2, 44-45.

[15] Duru Majesty, K.C., Agomuo E.A. and Amadi, B.A. (2012) Nutrient composition of "Nduduagworagwo", a traditional food of Akokwa people in Ideato North L.G.A of Imo State, Nigeria.

[16] National Research Council (1975) Recommended daily dietary allowance. Nutr. Rev, 31, 373-395.

[17] Kritchevsky, D. (1996) Food lipids and artherosclerosis. Food lipids and health. Dekker, New York, 18-24.

[18] Obidoa, O., Joshua, P.E. and Eze, N.J. (2010) Phytochemical analysis of Cocos nicifera L. Journal of Pharmacy Research, 3, 280-296.

[19] Ishida, H., Suzuno, H., Sugiyama, N., Innami, S., Todoro, T. and Maekawa, A. (2000) Nutritional evaluation of chemical components of leaves, stalks and stem of sweet potatoes (Ipomea betatas poir). Food Chemistry, 68, 359-367. doi:10.1016/S0308-8146(99)00206-X

[20] Lewicki, P.P. (2004). Water as the determinant of food engineering properties. A review. Journal of Food Engineering, 61, 483-495. doi:10.1016/S0260-8774(03)00219-X

[21] Butts, C.L., Mishoe, J.W. and Chau, K.V. (1990) Measuring the thermal diffusivity of soil. Transaction of ASAE, 33, 179-184. 